\title{
SPRING-WATER AS AN ALTERNATIVE RESOURCE AFTER EARTHQUAKE FOR VILLAGERS, KOTA BELUD SABAH
}

\author{
Rohana Tair*, Laurine Dell \\ Faculty of Sciences and Natural Resources, University Malaysia Sabah, UMS Road, 88400 Kota Kinabalu Sabah. \\ *Corresponding Author Email: rohana@ums.edu.my
}

This is an open access article distributed under the Creative Commons Attribution License, which permits unrestricted use, distribution, and reproduction in any medium, provided the original work is properly cited

\section{ARTICLE DETAILS}

\section{Article History:}

Received 12 November 2017 Accepted 12 December 2017 Available online 1 January 2018

\section{ABSTRACT}

The earthquake natural disaster at Kundasang Ranau, Sabah in Jun 2015 has strongly impacted the source of water supply in Kota Belud district. Kota Belud is located downstream from Mount Kinabalu, where the source of water for the district once came from before the natural disaster occurred. The earthquake forced the local communities to source for alternative water supply for survival i.e spring-water, also known as gravity water by local communities. The locals depend on the alternative resource to survive even though the water is untreated both physically and chemically. This study aims to determine the concentration of heavy metals $(\mathrm{Pb}, \mathrm{Cu}, \mathrm{Cr}, \mathrm{and} \mathrm{Cd})$ and water quality $(\mathrm{pH}$ value, turbidity, temperature, biological oxygen demand, total dissolved solids and total suspended solids) in spring-water from two selected villages; Bukit Bendera and Tamalang, Kota Belud. The samples were collected from two different sources; from the spring-water catchment in the upper hill and from the end user's house water pipes for domestic usages. Sampling repetition was done three times. The results show that there were significant differences $(\mathrm{P}<0.05)$ found for $\mathrm{pH}$ value, turbidity, temperature, total dissolved solids, total suspended solids and $\mathrm{Pb}$ for heavy metals at different areas (hill \& house) throughout the sampling repetitions. In addition, the turbidity, BOD, and Cd level were found to exceed the permissible level as drinking water. The spring-water at Bukit Bendera and Tamalang village, Kota Belud are safe to use for washing but is not suitable as human consumptions, unless filtered. In conclusion, monitoring of the spring-water quality as an alternative resource after the earthquake is very important as well as precautionary actions for future natural disasters in Sabah.

\section{KEYWORDS}

Kota Belud, Sabah, Earthquake, Spring Water, Alternative Water Resources.

\section{INTRODUCTION}

The earthquake in Ranau, Sabah on $5^{\text {th }}$ June 2015 with a magnitude of 6.0 was an unpredictable natural disaster. This event caused water supply disruptions especially to areas that depended on water flows from Mount Kinabalu. Mount Kinabalu is located in the middle of the State of Sabah and acts as water channel in the upstream areas. Kota Belud district is located downstream closest to Mount Kinabalu, where Kedamaian River flows; as the main source at the water treatment plant for Kota Belud district. Resulting from the quake, the river was contaminated and harmful due to the extremely fast flow and suspended materials, mainly sand and soil due to river banks erosion. This condition affected the clean water supply to Kota Belud residents as the water treatment plant had to be closed due to the extremely dangerous river conditions. Therefore, residents of Kota Belud are forced to find alternative water source for daily use as the river will take time to recover to its best state.

The villagers of Bukit Bendera and Tamalang, Kota Belud (Figure 1) took the initiative to find the alternative water sources in the upper hill areas. A few years ago, there was spring-water catchment made by the government on the upper hill in the village and currently villagers depended on it for clean water supply after the natural disaster. The spring-water system is built on the hillside area and is channelled to houses by using a plasticized polyvinyl chloride pipes (PVC pipe). There are two sizes of pipes used; 5 inches and 1 inch respectively (Figure 2 \& $3)$. The 5-inch pipe is used to connect the water reservoirs on the hill to the storage tank outside the users' communal area, while the 1-inch pipes are used to connect the storage tank directly to homes. Although the spring-water channelled into homes is not treated before domestic usages, there are no other options for the communities. The spring-water is still being channelled to residents' homes as disaster precautionary steps.

The water resource is known to local villagers as gravity water because it is an underground water supply system that comes from a spring in high altitude area. The water flow depends on the gravity; flowing from upper area to lower area [1]. Gravity water is also known as spring-water [1, 2]. Springs can be formed in various types of rocks, but most of them are found in limestone and dolomite, which are easily readable and can be dissolved by rainwater which in turn causes acidity in the water [3]. When the rocks are dissolved and cracked, spaces will form which allow the flow of water to pass through. If the flow of water is saturated, then it will flow to the surface of the earth as a spring. The spring-water is an important source of water in rural areas.

Natural disasters are an unpredictable natural phenomenon that happens on the earth. This natural event of flood, earthquake, or hurricane causes great damage or loss of life. Earthquake is the major natural disaster that happens all over the world. The impact could be huge, and it can take many years to recover. However, there are many guidelines to assess the impact of natural disaster [2]. Typically, the impact to human is more important [4]. Everyday life can be disturbed especially when the water and electricity supply get automatically cut off after a disaster $[2,4,5]$. The history of Great East Japan Earthquake at Kagoshima in the year 2011 proved that spring-water is the alternative resource of water for the victims' survival [2]. Water is important for daily life especially for drinking water [6]. Monitoring the quality of water resources for drinking water is much important during the disaster events as the contaminant presents in many form such as biological, chemical and physical especially in natural and anthropogenic pollutant [7-12].

The objectives of this study are (1) to determine the insitu parameter $(\mathrm{pH}$ value, turbidity, temperature, biological oxygen demand, total dissolved solids and total suspended solids) for spring-water quality in the villages of Bukit Bendera and Tamalang in Kota Belud area; (2) to determine the concentration of heavy metals $(\mathrm{Pb}, \mathrm{Cu}, \mathrm{Cr}$, and $\mathrm{Cd}$ ) in spring-water; and (3) to determine the quality of spring-water for household consumption by using the water quality standards and drinking water standard of Malaysia and USEPA, 2009. 


\section{METHODOLOGY}

\subsection{Study Sites}

The study sites were at Bukit Bendera village $\left(06^{0} 15.358^{\prime} \mathrm{N} 116^{0} 26.856^{\prime}\right.$ E) and Tamalang village $\left(06^{\circ} 14.089^{\prime} \mathrm{N} 116^{\circ} 26.760^{\prime}\right.$ E) at Kota Belud Sabah. Sampling was done for three times: during the rainy season $(9$ February 2016), inter-season (rainy-dry) (23 February 2016) and the dry season (28 March 2016). Also, there were two areas for samples collections which were from the main spring-water catchment on the upper hill and from 12 selected houses from both study sites.

\subsection{Insitu parameter measurement and sampling}

The in-situ parameters were measured by using YSI meter as were $\mathrm{pH}$ value, temperature and turbidity, respectively. Next, water samples were collected by using $500 \mathrm{~mL}$ polyethylene bottles and keep it in the cooler box with the temperature less than $4^{\circ} \mathrm{C}$ before transferred to the laboratory for analysis [1].

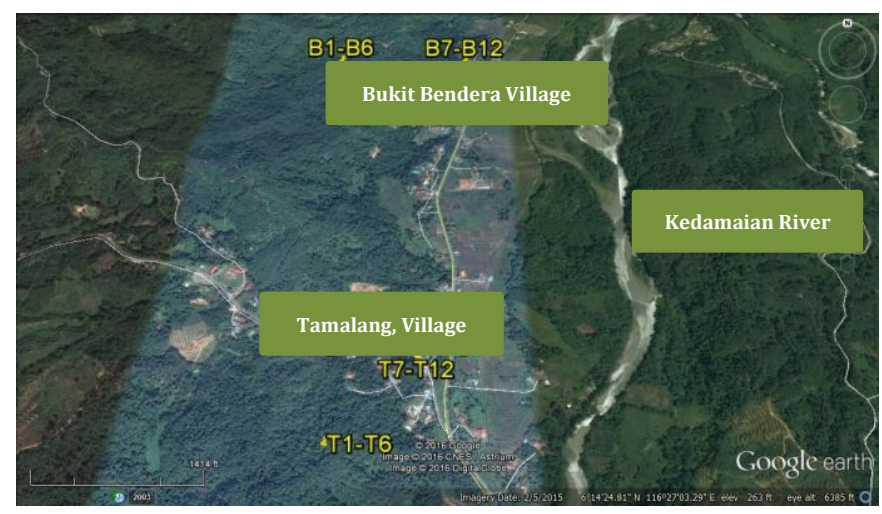

Figure 1: Locations of Bukit Bendera and Tamalang Village, Kota Belud Sabah

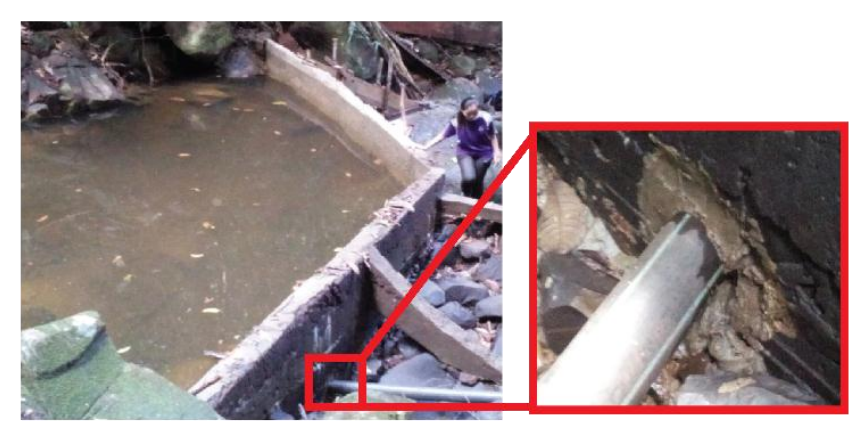

Figure 2: The spring-water catchment at the upper hill area, Bukit Bendera village and the plugged 5 inches PVC pipe.

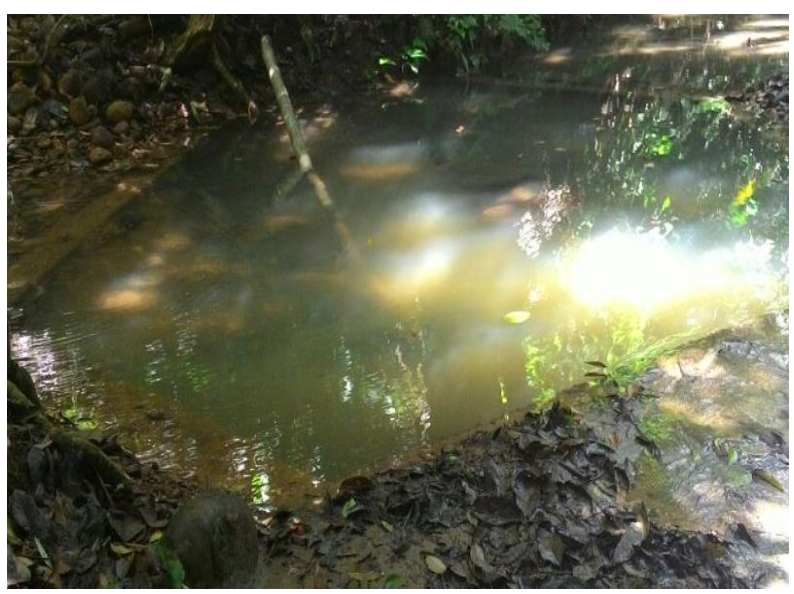

Figure 3: The spring-water catchment at the upper hill area, Tamalang village.

Table 1: Coordinate for sampling sites.

\begin{tabular}{|c|c|c|c|c|c|}
\hline \multicolumn{3}{|c|}{ Bukit Bendera Village } & \multicolumn{3}{|c|}{ Tamalang Village } \\
\hline Stations & Area & Coordinate & Stations & Area & Coordinate \\
\hline \multirow[t]{2}{*}{ B1 } & Hill & N 060 15.358' & $\mathrm{T} 1$ & Hill & N $06^{0} 14.089^{\prime}$ \\
\hline & & E $116^{0} 26.856^{\prime}$ & & & E $116^{0} 26.760^{\prime}$ \\
\hline \multirow[t]{2}{*}{ B2 } & Hill & N $06^{0} 15.358^{\prime}$ & $\mathrm{T} 2$ & Hill & N $06^{0} 14.089^{\prime}$ \\
\hline & & E $116^{0} 26.856^{\prime}$ & & & E $116^{0} 26.760^{\prime}$ \\
\hline \multirow[t]{2}{*}{ B3 } & Hill & N $06^{0} 15.358^{\prime}$ & T3 & Hill & N $06^{0} 14.089^{\prime}$ \\
\hline & & E $116^{0} 26.856^{\prime}$ & & & E $116^{0} 26.760^{\prime}$ \\
\hline \multirow[t]{2}{*}{ B4 } & Hill & N $06^{0} 15.358^{\prime}$ & $\mathrm{T} 4$ & Hill & N $06^{0} 14.089^{\prime}$ \\
\hline & & E $116^{0} 26.856^{\prime}$ & & & E $116^{0} 26.760^{\prime}$ \\
\hline \multirow[t]{2}{*}{ B5 } & Hill & N $06^{0} 15.358^{\prime}$ & $\mathrm{T} 5$ & Hill & N $06^{0} 14.089^{\prime}$ \\
\hline & & E $116^{0} 26.856^{\prime}$ & & & E $116^{0} 26.760^{\prime}$ \\
\hline \multirow[t]{2}{*}{ B6 } & Hill & N $06^{0} 15.358^{\prime}$ & $\mathrm{T} 6$ & Hill & N $06^{0} 14.089^{\prime}$ \\
\hline & & E $116^{0} 26.856^{\prime}$ & & & E $116^{\circ} 26.760^{\prime}$ \\
\hline \multirow[t]{2}{*}{ B7 } & Villager house & N $06^{0} 15.098^{\prime}$ & $\mathrm{T} 7$ & Villager house & N $06^{0} 14.238^{\prime}$ \\
\hline & & E $116^{0} 26.937^{\prime}$ & & & E $116^{0} 26.855^{\prime}$ \\
\hline \multirow[t]{2}{*}{ B8 } & Villager house & N $06^{0} 15.100^{\prime}$ & $\mathrm{T} 8$ & Villager house & N $06^{0} 14.247^{\prime}$ \\
\hline & & E $116^{0} 26.929^{\prime}$ & & & E $116^{0} 26.861^{\prime}$ \\
\hline \multirow[t]{2}{*}{ B9 } & Villager house & N $06^{0} 15.114^{\prime}$ & T9 & Villager house & N $06^{0} 14.259^{\prime}$ \\
\hline & & E $116^{0} 26.927^{\prime}$ & & & E $116^{0} 26.863^{\prime}$ \\
\hline \multirow[t]{2}{*}{ B10 } & Villager house & N $06^{0} 15.128^{\prime}$ & $\mathrm{T} 10$ & Villager house & N $06^{0} 14.275^{\prime}$ \\
\hline & & E $116^{0} 26.922^{\prime}$ & & & E $116^{0} 26.870^{\prime}$ \\
\hline \multirow[t]{2}{*}{ B11 } & Villager house & N $06^{0} 15.137^{\prime}$ & $\mathrm{T} 11$ & Villager house & N $06^{0} 14.281^{\prime}$ \\
\hline & & E $116^{0} 26.924^{\prime}$ & & & E $116^{0} 26.871^{\prime}$ \\
\hline \multirow[t]{2}{*}{ B12 } & Villager house & N $06^{0} 15.117^{\prime}$ & $\mathrm{T} 12$ & Villager house & N $06^{0} 14.223^{\prime}$ \\
\hline & & E $116^{0} 26.926^{\prime}$ & & & E $116^{0} 26.856^{\prime}$ \\
\hline
\end{tabular}

\subsection{Heavy metals analysis}

The preservative method for heavy metals analysis in water was applied by added the $10 \%$ of nitric acid until pH 2.0 [13]. Next, $100 \mathrm{~mL}$ water sample was filtered by using membrane filter $0.45 \mu \mathrm{m}$ before analysed it by using ICP-OES.

\section{$2.4 \quad$ BOD $_{5}$ Analysis}

The water samples for BOD $_{5}$ analysis was done within 24 hours especially for $\mathrm{BOD}_{1}$. The reading of $\mathrm{BOD}_{1}$ is measured on the first day while $\mathrm{BOD}_{5}$ is taken after 5 days. The incubation temperature for $\mathrm{BOD}_{5}$ is $20^{\circ} \mathrm{C}$. The method was used is the iodometric titration [14].
$\mathrm{BOD}_{5}=\mathrm{DO}_{1}-\mathrm{DO}_{5}$

Where,

$\mathrm{BOD}_{5}=$ Biological Oxygen Demand based on 5-day incubation (in mg/L) $\mathrm{DO}_{1}=$ Dissolved Oxygen on the first day (in $\mathrm{mg} / \mathrm{L}$ )

$\mathrm{DO}_{5}=$ Dissolved Oxygen on the $5^{\text {th }}$ day of incubation (in $\mathrm{mg} / \mathrm{L}$ )

\subsection{Total dissolved solids and Total suspended solids}

The gravimetric method was applied to determine the dissolved solids and suspended solids in $100 \mathrm{~mL}$ spring-water samples. For dissolved solids; the spring-water sample is collected after pass through the standard glassfibre filter by using vacuum pump and dried at temperature $180^{\circ} \mathrm{C}$. The weight of water sample was measured before and after drying process; the difference of weight is representing the dissolved solids. For suspended solids; the standard glass-fibre filter is then dried at the temperature of $105^{\circ} \mathrm{C}$ for 1 hour. The weight of filter was measured before and after 
drying process; the difference of weight is representing the suspended solids. Next, the formula as below is used for the calculations [14].

Dissolved solids $=($ DR-D $) \times 1000 \mathrm{~V}$

Where,

$\mathrm{DR}=$ Weight of evaporating dish + dried residue (in $\mathrm{mg}$ )

$\mathrm{D}=$ Weight of evaporating dish (in $\mathrm{mg}$ )

$\mathrm{V}=$ Volume of water sample (in $\mathrm{mL}$ )

\section{RESULTS AND DISCUSSIONS}

Regarding to the water quality from Bukit Bendera and Tamalang village, Kota Belud, there were significant differences found for the $\mathrm{pH}$ value, turbidity, temperature, total dissolved solids, total suspended solids and $\mathrm{Pb}$ for heavy metals. The three interval sampling times and different sampling areas (water catchment on upper hill and houses) were influenced the significant difference in the spring-water quality.

The $\mathrm{pH}$ value at Tamalang village is found higher than Bukit Bendera village especially at the houses area. The differences were significant $(p<0.05)$ and it is proven by the ANOVA two way (Table $3 \& 4)$. Where, there were significant different between area (hill and houses) and the samplings time $(\mathrm{P}<0.05)$. In addition, there were interactions of $\mathrm{pH}$ value between areas and sampling times found at Tamalang village but not at Bukit Bendera village, respectively. So, the quality of $\mathrm{pH}$ value for springwater at Tamalang village always changing and influenced by many factors especially the weather (rainy and dry season). There are similar trends were reported by a researcher in Nkoro river, Nigeria where the $\mathrm{pH}$ value found lower at upstream compared to downstream because of the seasonal variations $[15,16]$. In addition, the rainy and dry season influenced the $\mathrm{pH}$ level due to imbalance level of $\mathrm{H}^{+}$ions input from surface run-offs during the rains [15]. The Pearson correlation (Table 6) also supports that there were other factors influenced the changing of $\mathrm{pH}$ value which were turbidity $(\mathrm{r}=0.702)$, temperature $(\mathrm{r}=0.675)$, BOD $(\mathrm{r}=-0.862)$, TSS $(r=0.833)$ and TDS $(r=0.752)(\mathrm{P}<0.01)$, respectively. As a result, the $\mathrm{pH}$ value range is 6.720 to 7.023 and the level is still under the permissible for the water quality standard and drinking water standard (Table 7).

Table 2: The mean concentrations of parameters in spring-water from Bukit Bendera and Tamalang village for three-time samplings, Kota Belud, Sabah.

\begin{tabular}{|c|c|c|c|c|c|}
\hline Parameters & Mean \pm SD & Locations & Area & Mean \pm SD & Parameters \\
\hline \multirow[t]{4}{*}{$\mathrm{pH}$} & $6.720 \pm 0.307$ & Bukit Bendera & Hill & $0.014 \pm 0.009$ & \multirow{4}{*}{$\begin{array}{l}\text { Total suspended solid } \\
\text { (mg/L) }\end{array}$} \\
\hline & $6.893 \pm 0.242$ & Bukit Bendera & House & $0.022 \pm 0.022$ & \\
\hline & $6.756 \pm 0.200$ & Tamalang & Hill & $0.008 \pm 0.004$ & \\
\hline & $7.023 \pm 0.179$ & Tamalang & House & $0.013 \pm 0.006$ & \\
\hline \multirow[t]{4}{*}{ Turbidity (NTU) } & $1.814 \pm 0.766$ & Bukit Bendera & Hill & $0.015 \pm 0.002$ & \multirow[t]{4}{*}{$\begin{array}{l}\mathrm{Pb} \\
(\mathrm{mg} / \mathrm{L})\end{array}$} \\
\hline & $2.708 \pm 0.943$ & Bukit Bendera & House & $0.014 \pm 0.002$ & \\
\hline & $0.877 \pm 0.308$ & Tamalang & Hill & $0.013 \pm 0.002$ & \\
\hline & $1.701 \pm 0.456$ & Tamalang & House & $0.015 \pm 0.002$ & \\
\hline \multirow[t]{4}{*}{$\begin{array}{l}\text { Temperature } \\
\left({ }^{\circ} \mathrm{C}\right)\end{array}$} & $25.817 \pm 2.312$ & Bukit Bendera & Hill & $0.011 \pm 0.001$ & \multirow[t]{4}{*}{$\begin{array}{l}\mathrm{Cu} \\
(\mathrm{mg} / \mathrm{L})\end{array}$} \\
\hline & $31.306 \pm 1.951$ & Bukit Bendera & House & $0.011 \pm 0.001$ & \\
\hline & $25.706 \pm 0.914$ & Tamalang & Hill & $0.011 \pm 0.001$ & \\
\hline & $31.328 \pm 1.302$ & Tamalang & House & $0.011 \pm 0.001$ & \\
\hline \multirow[t]{4}{*}{ BOD } & $2.078 \pm 0.703$ & Bukit Bendera & Hill & $0.013 \pm 0.002$ & \multirow[t]{4}{*}{$\begin{array}{l}\mathrm{Cr} \\
(\mathrm{mg} / \mathrm{L})\end{array}$} \\
\hline & $2.890 \pm 0.976$ & Bukit Bendera & House & $0.012 \pm 0.001$ & \\
\hline & $1.839 \pm 0.762$ & Tamalang & Hill & $0.012 \pm 0.001$ & \\
\hline & $3.106 \pm 0.694$ & Tamalang & House & $0.012 \pm 0.001$ & \\
\hline \multirow[t]{4}{*}{$\begin{array}{l}\text { Total Dissolved solid } \\
\text { (mg/L) }\end{array}$} & $400.00 \pm 0.00$ & Bukit Bendera & Hill & $0.011 \pm 0.001$ & \multirow[t]{4}{*}{$\begin{array}{l}\text { Cd } \\
(\mathrm{mg} / \mathrm{L})\end{array}$} \\
\hline & $394.44 \pm 41.62$ & Bukit Bendera & House & $0.011 \pm 0.001$ & \\
\hline & $200.00 \pm 0.00$ & Tamalang & Hill & $0.011 \pm 0.001$ & \\
\hline & $305.55 \pm 23.57$ & Tamalang & House & $0.011 \pm 0.001$ & \\
\hline
\end{tabular}

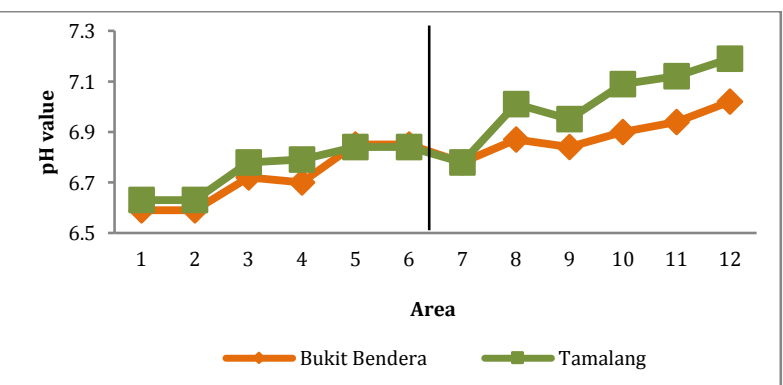

(a)

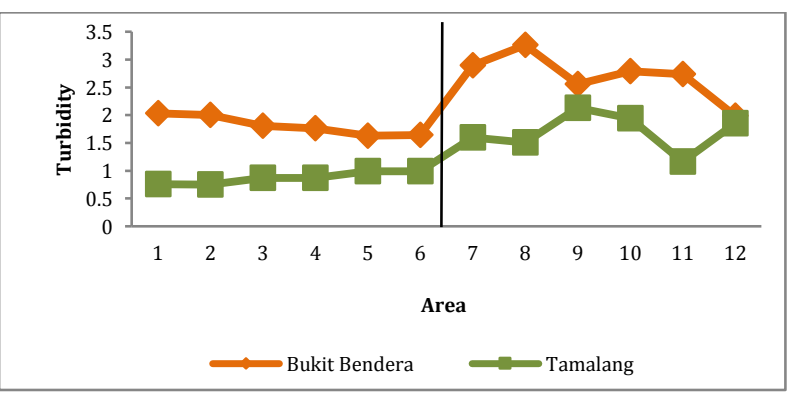

(b)

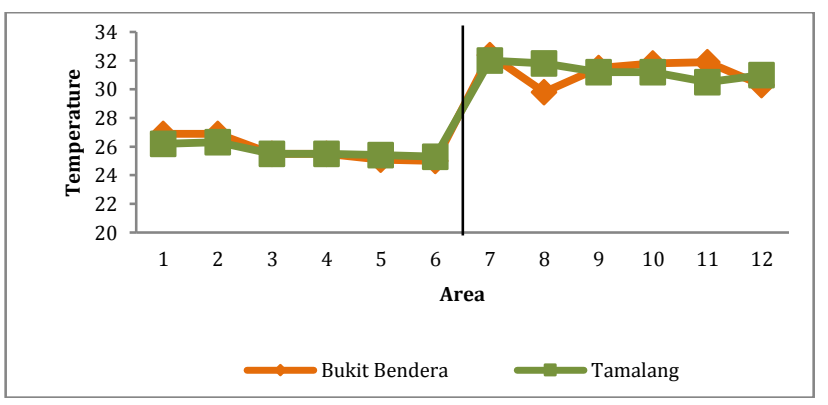

(c)

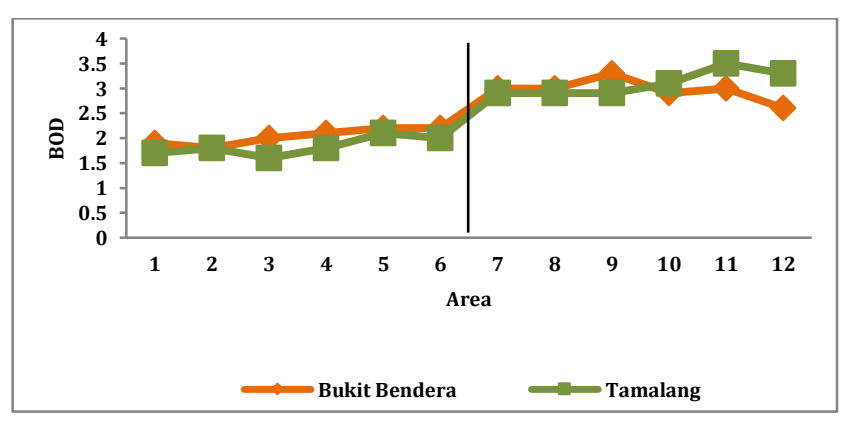

(d) 


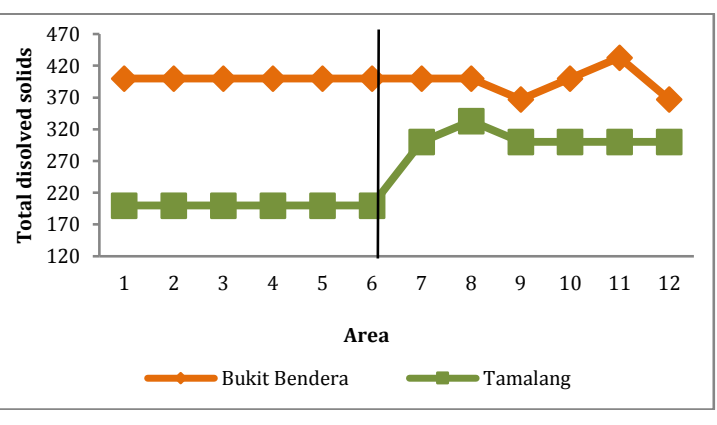

(e)

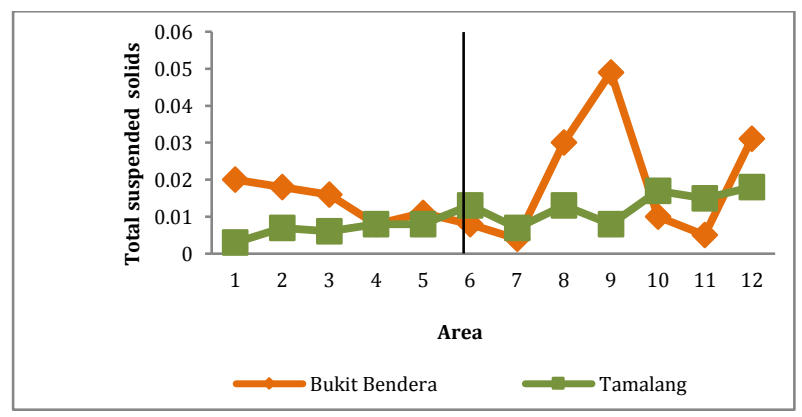

(f)

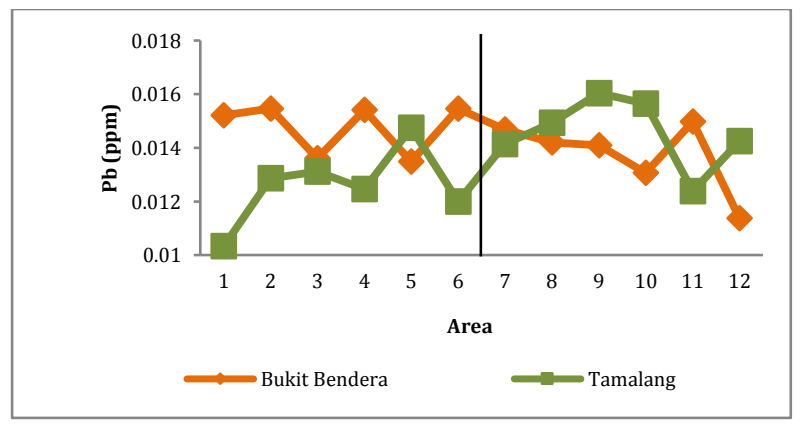

(g)

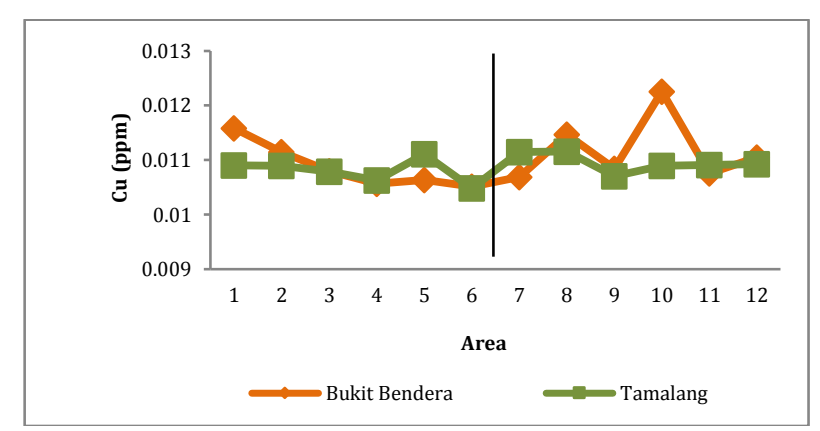

(h)

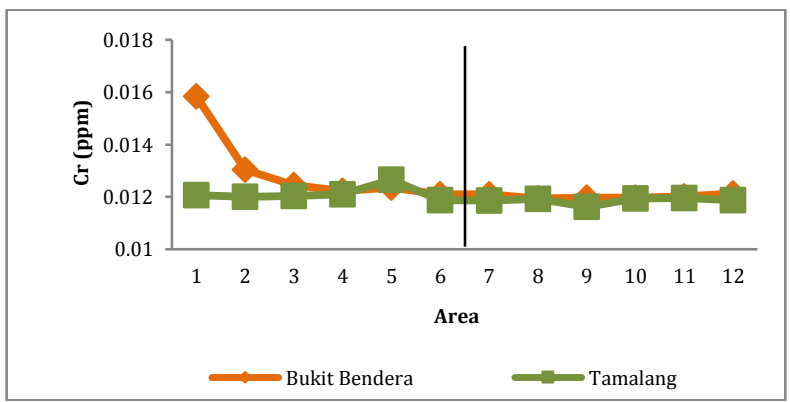

(i)

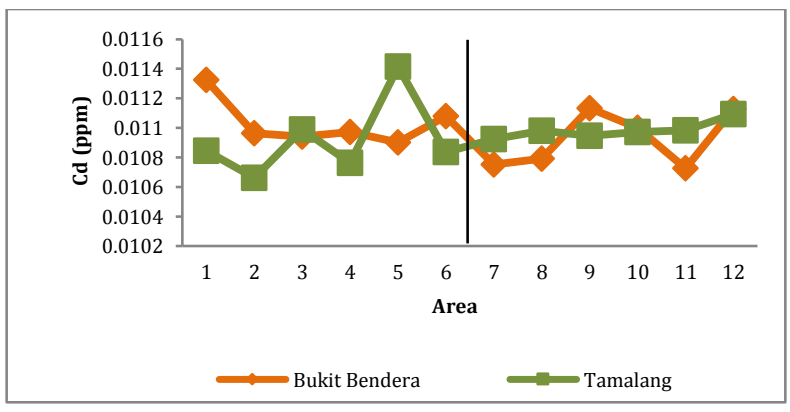

(j)

Figure 1: The trends of parameters concentration from the two different areas; hill (1-6) to the villager's houses (7-12) for Bukit Bendera and Tamalang village, Kota Belud, Sabah; a) pH value b) Turbidity c)Temperature d) BOD e) Total dissolved solids f) Total suspended solids g) Pb h) Cu i) Cr and j) Cd.

Table 3: The ANOVA Two Way for spring-water at Bukit Bendera village, Kota Belud.

\begin{tabular}{|c|c|c|c|c|c|c|}
\hline Bukit Bendera & Source of Variation & SS & $d f$ & $M S$ & P-value & Significant \\
\hline \multirow[t]{3}{*}{$\mathrm{pH}$} & Area & 0.2704 & 1 & 0.2704 & 0.0263 & $<0.05$ \\
\hline & Sampling & 0.9805 & 2 & 0.4903 & 0.0005 & $<0.05$ \\
\hline & Area-Sampling & 0.1327 & 2 & 0.0663 & 0.2772 & $>0.05$ \\
\hline \multirow[t]{3}{*}{ Turbidity } & Area & 7.2003 & 1 & 7.2003 & $9.9 \mathrm{E}-07$ & $<0.05$ \\
\hline & Sampling & 18.8471 & 2 & 9.4236 & $3.49 \mathrm{E}-10$ & $<0.05$ \\
\hline & Area-Sampling & 0.4621 & 2 & 0.2311 & 0.3144 & $>0.05$ \\
\hline \multirow[t]{3}{*}{ Temperature } & Area & 271.1511 & 1 & 271.1511 & $1.87 \mathrm{E}-11$ & $<0.05$ \\
\hline & Sampling & 48.4956 & 2 & 24.2478 & 0.0006 & $<0.05$ \\
\hline & Area-Sampling & 31.7089 & 2 & 15.8544 & 0.0052 & $<0.05$ \\
\hline \multirow[t]{3}{*}{ BOD } & Area & 5.9373 & 1 & 5.9373 & $6.35 \mathrm{E}-05$ & $<0.05$ \\
\hline & Sampling & 15.9740 & 2 & 7.9870 & $9.71 \mathrm{E}-08$ & $<0.05$ \\
\hline & Area-Sampling & 0.3420 & 2 & 0.1710 & 0.5440 & $>0.05$ \\
\hline \multirow[t]{3}{*}{ Total suspended solid } & Area & 277.7778 & 1 & 277.7778 & 0.5398 & $>0.05$ \\
\hline & Sampling & 3888.8889 & 2 & 1944.4444 & 0.0841 & $>0.05$ \\
\hline & Area-Sampling & 3888.8889 & 2 & 1944.4444 & 0.0841 & $>0.05$ \\
\hline \multirow[t]{3}{*}{ Total dissolved solid } & Area & 0.0005 & 1 & 0.0005 & 0.1413 & $>0.05$ \\
\hline & Sampling & 0.0024 & 2 & 0.0012 & 0.0121 & $<0.05$ \\
\hline & Area-Sampling & 0.0002 & 2 & 8.27E-05 & 0.7064 & $>0.05$ \\
\hline \multirow[t]{3}{*}{$\mathbf{P b}$} & Area & $6.57 \mathrm{E}-06$ & 1 & $6.57 \mathrm{E}-06$ & 0.2530 & $>0.05$ \\
\hline & Sampling & $9.63 \mathrm{E}-07$ & 1 & $9.63 \mathrm{E}-07$ & 0.6572 & $>0.05$ \\
\hline & Area-Sampling & $9.91 \mathrm{E}-06$ & 1 & $9.91 \mathrm{E}-06$ & 0.1638 & $>0.05$ \\
\hline \multirow[t]{3}{*}{$\mathrm{Cu}$} & Area & $5.47 \mathrm{E}-07$ & 1 & $5.47 \mathrm{E}-07$ & 0.4294 & $>0.05$ \\
\hline & Sampling & $1.81 \mathrm{E}-06$ & 1 & $1.81 \mathrm{E}-06$ & 0.1579 & $>0.05$ \\
\hline & Area-Sampling & $5.28 \mathrm{E}-07$ & 1 & $5.28 \mathrm{E}-07$ & 0.4370 & $>0.05$ \\
\hline
\end{tabular}




\begin{tabular}{|c|c|c|c|c|c|c|}
\hline $\mathrm{Cr}$ & Area & 5.77E-06 & 1 & 5.77E-06 & 0.1165 & $>0.05$ \\
\hline \multirow{5}{*}{ Cd } & Sampling & $6.01 \mathrm{E}-06$ & 1 & $6.01 \mathrm{E}-06$ & 0.1094 & $>0.05$ \\
\hline & Area-Sampling & $3.71 \mathrm{E}-06$ & 1 & $3.71 \mathrm{E}-06$ & 0.2030 & $>0.05$ \\
\hline & Area & 7.07E-08 & 1 & 7.07E-08 & 0.3385 & $>0.05$ \\
\hline & Sampling & $1.02 \mathrm{E}-09$ & 1 & $1.02 \mathrm{E}-09$ & 0.9073 & $>0.05$ \\
\hline & Area-Sampling & $2.55 \mathrm{E}-08$ & 1 & $2.55 \mathrm{E}-08$ & 0.5629 & $>0.05$ \\
\hline
\end{tabular}

For temperature, the result shows the data is slightly up from the hill areas to the houses areas at both study sites (Figure 1c). The temperature increased from $25.817^{\circ} \mathrm{C}$ to $31.328^{\circ} \mathrm{C}$ at Bukit Bendera village and 25.706 ${ }^{\circ} \mathrm{C}$ to $31.328{ }^{\circ} \mathrm{C}$ at Tamalang village, respectively (Table 2). From the observation, the villagers from Bukit Bendera and Tamalang are used PVC pipes as the main connector to supply the spring-water from the water catchment on hill areas to the houses. The temperature of spring-water might be changed during transferred from water catchment to storage tank using PVC pipes. The storage tank contributes the temperature quality changes because it's exposed directly to the sunlight every day before used by the villagers at home. ANOVA two way supported that the sampling times and different areas have significant difference $(\mathrm{P}<0.05)$ (Table $3 \& 4$ ). So, the different weather during sampling was influence the temperature in the storage tank. Also, there are another factor might influence the temperature in the spring-water which were $\mathrm{Pb}$ and BOD $(0.607<\mathrm{r}<0.912, \mathrm{P}<0.01)$, respectively (Table 5 \& 6).

Table 4: The ANOVA Two Way for spring-water at Tamalang village, Kota Belud.

\begin{tabular}{|c|c|c|c|c|c|c|}
\hline Tamalang & Source of Variation & sS & $d f$ & MS & P-value & Significant \\
\hline \multirow[t]{3}{*}{ pH } & Area & 0.6427 & 1 & 0.6427 & $7.877 \mathrm{E}-06$ & $<0.05$ \\
\hline & Sampling & 0.3955 & 2 & 0.1978 & 0.0009 & $<0.05$ \\
\hline & Area-Sampling & 0.1610 & 2 & 0.0805 & 0.0387 & $<0.05$ \\
\hline \multirow{3}{*}{ Turbidity } & Area & 6.1091 & 1 & 6.1091 & $3.964 \mathrm{E}-07$ & $<0.05$ \\
\hline & Sampling & 0.2303 & 2 & 0.1152 & 0.4653 & $>0.05$ \\
\hline & Area-Sampling & 0.5033 & 2 & 0.2517 & 0.1971 & $>0.05$ \\
\hline \multirow{3}{*}{ Temperature } & Area & 284.4844 & 1 & 284.4844 & $9.513 \mathrm{E}-17$ & $<0.05$ \\
\hline & Sampling & 2.0517 & 2 & 1.0258 & 0.3771 & $>0.05$ \\
\hline & Area-Sampling & 10.4339 & 2 & 5.2169 & 0.0122 & $<0.05$ \\
\hline \multirow{2}{*}{ BOD } & Area & 14.4400 & 1 & 14.4400 & $8.7603 \mathrm{E}-12$ & $<0.05$ \\
\hline & Sampling & 14.0039 & 2 & 7.0019 & $7.8315 \mathrm{E}-11$ & $<0.05$ \\
\hline \multirow{4}{*}{ Total suspended solid } & Area-Sampling & 0.2817 & 2 & 0.1408 & 0.3390 & $>0.05$ \\
\hline & Area & 100277.778 & 1 & 100277.78 & $2.819 \mathrm{E}-18$ & $<0.05$ \\
\hline & Sampling & 555.5556 & 2 & 277.7778 & 0.3798 & $>0.05$ \\
\hline & Area-Sampling & 555.5556 & 2 & 277.7778 & 0.3798 & $>0.05$ \\
\hline \multirow{3}{*}{ Total dissolved solid } & Area & 0.0003 & 1 & 0.0003 & 0.0029 & $<0.05$ \\
\hline & Sampling & 0.0001 & 2 & $7.05 \mathrm{E}-05$ & 0.0740 & $>0.05$ \\
\hline & Area-Sampling & $5.722 \mathrm{E}-06$ & 2 & $2.86 \mathrm{E}-06$ & 0.8915 & $>0.05$ \\
\hline \multirow{3}{*}{$\mathbf{P b}$} & Area & $2.346 \mathrm{E}-05$ & 1 & $2.346 \mathrm{E}-05$ & 0.0116 & $<0.05$ \\
\hline & Sampling & 8.692E-06 & 1 & 8.692E-06 & 0.1061 & $>0.05$ \\
\hline & Area-Sampling & $1.968 \mathrm{E}-08$ & 1 & $1.968 \mathrm{E}-08$ & 0.9366 & $>0.05$ \\
\hline \multirow{3}{*}{$\mathrm{Cu}$} & Area & $1.447 \mathrm{E}-07$ & 1 & $1.447 \mathrm{E}-07$ & 0.1389 & $>0.05$ \\
\hline & Sampling & $3.315 \mathrm{E}-07$ & 1 & $3.315 \mathrm{E}-07$ & 0.0302 & $<0.05$ \\
\hline & Area-Sampling & $2.216 \mathrm{E}-08$ & 1 & $2.216 \mathrm{E}-08$ & 0.5533 & $>0.05$ \\
\hline \multirow{3}{*}{$\mathrm{Cr}$} & Area & 4.047E-07 & 1 & 4.047E-07 & 0.0292 & $<0.05$ \\
\hline & Sampling & $9.308 \mathrm{E}-09$ & 1 & $9.308 \mathrm{E}-09$ & 0.7254 & $>0.05$ \\
\hline & Area-Sampling & $3.166 \mathrm{E}-07$ & 1 & 3.166E-07 & 0.0509 & $>0.05$ \\
\hline \multirow{3}{*}{ Cd } & Area & $2.551 \mathrm{E}-08$ & 1 & $2.551 \mathrm{E}-08$ & 0.5654 & $>0.05$ \\
\hline & Sampling & $7.284 \mathrm{E}-08$ & 1 & $7.284 \mathrm{E}-08$ & 0.3350 & $>0.05$ \\
\hline & Area-Sampling & $1.317 \mathrm{E}-07$ & 1 & $1.317 \mathrm{E}-07$ & 0.1991 & $>0.05$ \\
\hline
\end{tabular}

The concentrations of turbidity were in range of 1.814 NTU to 2.708 NTU for Bukit Bendera village and 0.877 NTU to 1.701 NTU for Tamalang village, respectively. The concentration shows that the level was over the water quality standard and drinking water standard (Table 7). The concentration at houses areas was slightly higher than spring-water catchment on hill areas (Table 2) and the results were supported by the ANOVA two way $(\mathrm{P}<0.05)$ (Table $3 \& 4)$. The turbidity concentrations show that the quality of spring-water supplied to the houses is not filtered before used or consumed by the villagers. The unfiltered spring-water is proven by the value of BOD in the water. Where, the biological organism is still present in the water. The BOD range is between 2.078 to 2.890 for Bukit Bendera village and 1.839 to 3.106 for Tamalang village, respectively. The Pearson correlation shows that turbidity has strong relationship with $\mathrm{BOD}(0.800<\mathrm{r}<0.813, \mathrm{P}<0.05)$ (Table $5 \& 6)$. However, the BOD level is still under the permissible for the water quality standard and drinking water standard (Table 7).

Table 5: Person correlation for spring-water at Bukit Bendera village, Kota Belud.

\begin{tabular}{|c|c|c|c|c|c|c|c|c|c|c|}
\hline & $\mathrm{pH}$ & Turbidity & Temp & BOD & TSS & TDS & $\mathbf{P b}$ & $\mathrm{Cu}$ & $\mathrm{Cr}$ & Cd \\
\hline pH & 1 & & & & & & & & & \\
\hline Turbidity & 0.321 & 1 & & & & & & & & \\
\hline
\end{tabular}




\begin{tabular}{lllllllllll}
\hline Temp & 0.503 & $.846^{* *}$ & 1 & & & & & & & \\
BOD & $-0.675^{*}$ & $.813^{* *}$ & $.865^{* *}$ & 1 & & & & & \\
TSS & 0.125 & .165 & .212 & .316 & 1 & & & & \\
TDS & -.153 & .143 & -.077 & -.146 & $-.761^{* *}$ & 1 & & \\
Pb & $-.647^{*}$ & -.055 & -.301 & -.294 & -.348 & .541 & 1 & \\
Cu & .002 & .448 & .354 & .161 & -146 & -.036 &.- .28 & 1 & \\
Cr & $-.671^{*}$ & -.266 & -.314 & -.548 & .016 & .068 & 0.304 & .287 & 1 \\
Cd & -.270 & -.469 & -.293 & -.344 & .436 & -.567 & -.099 & .246 & $.619^{*}$ & 1 \\
\hline
\end{tabular}

**Significant at 0.01

* Significant at 0.05

Table 6: Person correlation for spring-water at Tamalang village, Kota Belud.

\begin{tabular}{|c|c|c|c|c|c|c|c|c|c|c|}
\hline & pH & Turbidity & Temp & BOD & TSS & TDS & $\mathbf{P b}$ & $\mathrm{Cu}$ & $\mathrm{Cr}$ & Cd \\
\hline pH & 1 & & & & & & & & & \\
\hline Turbidity & $.702^{*}$ & 1 & & & & & & & & \\
\hline Temp & $.675^{*}$ & $.853^{* *}$ & 1 & & & & & & & \\
\hline BOD & $-.862^{* *}$ & $.800^{* *}$ & $.912^{* *}$ & 1 & & & & & & \\
\hline TSS & $.833^{* *}$ & $.893^{* *}$ & .520 & $.732^{* *}$ & 1 & & & & & \\
\hline TDS & $.752^{* *}$ & $.836^{* *}$ & $.984^{* *}$ & $.927^{* *}$ & $.587^{*}$ & 1 & & & & \\
\hline $\mathbf{P b}$ & .533 & $.801^{* *}$ & $.607^{*}$ & .543 & .368 & $.621^{*}$ & 1 & & & \\
\hline $\mathrm{Cu}$ & .124 & .176 & .461 & .340 & -.011 & .442 & .331 & 1 & & \\
\hline $\mathrm{Cr}$ & -.269 & -.556 & -.571 & -.439 & -.258 & -.536 & -0.148 & .318 & 1 & \\
\hline Cd & .431 & .250 & .123 & .276 & .226 & .180 & .461 & .472 & .550 & 1 \\
\hline
\end{tabular}

**Significant at 0.01

* Significant at 0.05

For the TDS, Figure 1e \& 1f shows that the concentration of TDS and TSS is slightly higher from the spring-water catchment on hill areas to the houses especially for Tamalang village. There was significant difference for TDS and TSS $(\mathrm{P}<0.05)$ (Table 4). And, TSS have strong relationship to influence the TDS activity in spring-water at both sampling sites ($0.761<\mathrm{r}<0.587, \mathrm{P}<0.05$ ) (Table $5 \& 6$ ). Since the water-spring was not filtered, there were very strong significant correlation between TDS and TSS with BOD and turbidity $(0.732<\mathrm{r}<0.927, \mathrm{p}<0.01)$ at Tamalang village (Table 6). According to the TDS and TSS concentrations found that the spring-water quality from Bukit Bendera village was better than Tamalang Village. Fortunately, the TDS and TSS value for both villages shows the concentrations were under the permissible for the water quality standard and drinking water standard (Table 7).

For heavy metals, there is significant different for $\mathrm{Pb}, \mathrm{Cu}$ and $\mathrm{Cr}$ in springwater at Tamalang village but there is no significant different of heavy metals found at Bukit Bendera except for $\mathrm{Pb}$ (Table 4). The Pearson correlation shows there is strong relationship between $\mathrm{Pb}$ with $\mathrm{pH}(\mathrm{r}=$ $0.647, \mathrm{P}<0.05)$, turbidity $(\mathrm{r}=0.801, \mathrm{P}<0.01)$, temperature $(\mathrm{r}=0.607$, $\mathrm{P}<0.05)$ and TDS ( $\mathrm{r}=0.621, \mathrm{P}<0.05)$. Also, $\mathrm{Cr}$ and $\mathrm{Cd}(\mathrm{r}=0.619, \mathrm{P}<0.05), \mathrm{Cr}$ and $\mathrm{pH}(\mathrm{r}=-.0671, \mathrm{P}<0.05)$ (Table $5 \& 6)$. As a result, the heavy metal concentrations for both villages are under the permissible for the water quality standard and drinking water standard except for Cd (Table 7).

Table 7: The water quality standard and drinking water standard

\begin{tabular}{|c|c|c|c|c|}
\hline Parameters & $\begin{array}{l}\text { This Study } \\
\text { (Spring-water) }\end{array}$ & $\begin{array}{l}\text { National Water Quality } \\
\text { Standard for Malaysia (Class I) }\end{array}$ & $\begin{array}{l}\text { Drinking Water Quality } \\
\text { Standard, Ministry Health } \\
\text { of Malaysia }\end{array}$ & $\begin{array}{l}\text { The National Primary } \\
\text { Drinking Water Regulation } \\
\text { (USEPA, 2009) }\end{array}$ \\
\hline pH & $6.720-7.023$ & $6.5-8.5$ & $5.5-9.0$ & $6.5-8.5$ \\
\hline Turbidity (NTU) & $0.877-2.708$ & 5 & 1 & 1 \\
\hline Temperature $\left({ }^{\circ} \mathrm{C}\right)$ & $25.706-31.328$ & - & - & - \\
\hline BOD & $1.839-3.106$ & 1 (Class IIA=3) & 6.0 & - \\
\hline Total suspended Solid (mg/L) & & 25 & - & - \\
\hline Total disolved solid (mg/L) & $200-400$ & 500 & 1500 & - \\
\hline $\mathrm{Pb}(\mathrm{mg} / \mathrm{L})$ & $0.013-0.015$ & - (Class IIA=0.05) & 0.05 & 0.015 \\
\hline $\mathrm{Cu}(\mathrm{mg} / \mathrm{L})$ & 0.011 & - (Class IIA=0.02) & 1.0 & 1.3 \\
\hline $\mathrm{Cr}(\mathrm{mg} / \mathrm{L})$ & $0.012-0.013$ & $-($ Class IIA=0.05) & 0.05 & 0.1 \\
\hline $\mathrm{Cd}(\mathrm{mg} / \mathrm{L})$ & 0.011 & $-($ Class IIA=0.01) & 0.003 & 0.005 \\
\hline
\end{tabular}

\section{CONCLUSION}

The spring-water at Bukit Bendera and Tamalang village, Kota Belud is safe to use for washing but it is not suitable for drinking water unless the water is filtered and well treated. The qualities of spring-water were influenced by the $\mathrm{pH}$ value, turbidity, temperature, BOD, TDS, and $\mathrm{Pb}$ for both study sites. The turbidity, BOD and Cd level is found exceeded the permissible level as drinking water. For the conclusion, monitoring the spring-water or gravity-water quality is very important as alternative resources after the earthquake and as preparations for any other emergency natural disaster in study area.

\section{ACKNOWLEDGEMENT}

Thank you to Universiti Malaysia Sabah for the research grant purposely for earthquake natural disaster (DGB0001)

\section{REFERENCES}

[1] Jasik, M., Malek, S., Zelazny, M. 2017. Effect of water stage and tree stand composition on spatiotemporal differentiation of spring water chemistry draining Carpathian flysch slopes (Gorce Mts). Science of the Total Environment Journal, (599-600), 1630-1637. 
[2] Nanba, R., Takahashi, M., Tokuyama, M., Isogai, S. 2011. Effective Usage of Spring-water and Psychology of Consumer. SICE Annual Conference, September 13-18, Waseda University, Tokyo, Japan. Pp25522557.

[3] Page, R.M., Besmer, M.D., Epting, J., Sigrist, J.A., Hammes, F., Huggenberger, P. 2017. Online analysis: Deeper insights into water quality dynamics in spring water. Science of the Total Environment Journal, (599600), 227-236.

[4] Ozcelik, M. 2017. Alternative model for electricity and water supply after disaster. Journal of Taibah University for Science, 11, 966-974.

[5] Ohcoo, B., Valcour, J., Sarkar, A. 2017. Association between perceptions of public drinking water quality and actual drinking water quality: A community-based exploratory study in Newfoundland (Canada). Environmental Research Journal, 159, 435-443.

[6] Hamid, A., Salim, A.B., Sami, U.B., Arshid, J. 2016. Envirometric Techniques in Water Quality Assessment and Monitoring: A Case Study. Environmental Earth Science Journal, 75, 321(1-13).

[7] Awadh, S.M., Al-Ghani, A.A. 2013. Assessment of sulfurous springs in the west of Iraq for balneotherapy, drinking, irrigation and aquaculture purpose. Journal of the Society for Environmental Geochemistry and Health, 35 (4), 1-18.

[8] Ghanem, M., Ahmad, W. 2014. The Environmental effect of the spring water in Matwi catchment/ Palestine. Moroccan Journal Chemistry, 2 (5), 443-446.

[9] Garcia-Ruiz, J.M., Nakouzi, E., Kotopoulou, E. 2017. Biomimetic mineral self-organization from silica-rich spring water. Science Advance
Research Article, e1602285, 3, 1-6.

[10] Ghanem, M., Dare, A., Jebreen, H. 2017. Environmental spring water qualitative assessment in Natuf catchment-West Bank. Academia Journal of Environmental Science, 5 (10), 174-183.

[11] Arwenyo, B., Wasswa, J., Nyeko, M., Kasozi, G.N. 2017. The impact of septic systems density and nearness to spring water points, on water quality. African Journal of Environmental Science and Technology, 18C799761959:11-17. ISSN1996-0786.

[12] Song, C., Han, G., Wang, P., Shi, Y., He, Z. 2017. Hydrochemical and isotope characteristics of spring water discharging from Qiushe Loess Section in Lingtai, northwestern China and their implication to groundwater recharge. Journal of Groundwater Science and Engineering, 5 (4), 364-373.

[13] Sharma, B., Tyagi, S. 2013. Simplification of metal ion analysis in fresh water samples by Atomic Absorption Spectroscopy for laboratory students. Journal of Laboratory Chemical Education, 1 (3), 54-58.

[14] Abdullah, M.H. 2012. Principles in Water Analysis for Environmental Science. Universiti Malaysia Sabah Publisher. Kota Kinabalu Sabah, Malaysia, 68pp.

[15] Abowei, J.F.N. 2010. Salinity, Dissolved Oxygen, pH and surface water temperature conditions in Nkoro River, Niger Delta, Nigeria. Advance Journal of Food Science and Technology, 2 (1), 36-40.

[16] Razak, A.N.H., Praveena, S.M., Aris, A.Z., Hashim, Z. 2016. Quality of Kelantan drinking water and knowledge, attitude and practice among the population of Pasir Mas, Malaysia. Public Health Journal, 131, 103-111. 